\title{
Synthesis
}

\section{A Theory of Transformative Agency in Linked Social-Ecological Systems}

\author{
$\underline{\text { Frances R. Westley }}{ }^{1}, \underline{\text { Ola Tjornbo }}^{1}, \underline{\text { Lisen Schultz }}^{2}, \underline{\text { Per Olsson }}^{2}, \underline{\text { Carl Folke }}^{2}$, Beatrice Crona $^{2}$ and $\underline{\text { Örjan Bodin }}^{2}$
}

\begin{abstract}
We reviewed the literature on leadership in linked social-ecological systems and combined it with the literature on institutional entrepreneurship in complex adaptive systems to develop a new theory of transformative agency in linked socialecological systems. Although there is evidence of the importance of strategic agency in introducing innovation and transforming approaches to management and governance of such systems, there is no coherent theory to explain the wide diversity of strategies identified. Using Holling's adaptive cycle as a model of phases present in innovation and transformation of resilient socialecological systems, overlaid by Dorado's model of opportunity context (opaque, hazy, transparent) in complex adaptive systems, we propose a more coherent theory of strategic agency, which links particular strategies, on the part of transformative agents, to phases of system change.
\end{abstract}

Key Words: institutional entrepreneurship; skills; social innovation; transformation of linked social-ecological systems

\section{INTRODUCTION}

Humanity is facing major environmental challenges (Steffen et al. 2007). Innovative approaches to sustainability are urgently needed to deal with rapid large-scale changes (Galaz et al. 2008, Walker et al. 2009), steer away from potential Earth-system thresholds (Rockström et al. 2009), and build the resilience of social-ecological systems (SES) to deal with change as opportunity (Folke 2006, Westley et al. 2011). Previous research on resilience indicates that individuals have a key role to play in bringing about transformations for sustainability. Understanding how the agency of individuals can contribute to a sustainable future should therefore be a vital task of scholarship in the domain of resilience thinking (Westley 2002, Folke et al. 2005). We aim to bring together research on leadership in social-ecological systems with other work on agency in complex systems to create a new analytical framework for looking at transformative agency in socialecological systems.

Walker et al. (2004) have defined transformation as the capacity of people in a SES to create a new system when ecological, political, social, or economic conditions make the existing system untenable, suggesting that the agency of these people is a vital component in transformation. Many researchers recognize the need for sustainability transformations (Raskin et al. 1996, National Research Council 1999), but offer few empirically based insights into the kinds of agency that make transformation toward ecosystem-based management and governance possible (Olsson et al. 2008). We suggest that transformations are not just the product of a single individual's vision and steering; rather, they require systemic shifts in institutional underpinnings such as mental models, management routines, and resource flows (Westley and Antadze 2010, Olsson and Galaz 2012). Such shifts are often multilevel and multiphase processes, involving a variety of actors pursuing strategies that are attuned to opportunities arising from dynamic changes occurring within the system they are seeking to transform.

The importance of individual agency has been highlighted in several evaluations of the factors leading to shifts to ecosystem-based and adaptive management (Low and Randhir 2005, Pagdee et al. 2006, Fabricius et al. 2007, Pfueller 2008, Kenward et al. 2011). However, a coherent theory of the role of agents in these transformations, and the strategic actions they employ, is still lacking. There is a need for a contextual understanding of the relationship between different strategies and techniques actors utilize, and the broader system dynamics that shape the context in which they are working.

We first discuss the insights into agency that have emerged from research on linked social-ecological systems (Olsson et al. 2004, Folke et al. 2005, Chapin et al. 2010) and connect these to literature on entrepreneurship (social, policy, and institutional), which examines the role of strategic agency in the transformation of complex adaptive systems generally (Maguire et al. 2004, Dorado 2005, Westley et al. 2006). We also argue for the superiority of the concept of institutional entrepreneur (IE) over that of leadership for understanding effective agency in complex systems. Second, key insights from our review of IE literature are used to build an analytical framework that divides the process of SES transformation into stages, each associated with particular strategies and interventions of change agents that facilitate progress toward transformation.

\section{AGENCY AND LEADERSHIP IN COMPLEX SYSTEMS}

The notion that individual agency can be vital in shaping the dynamics of broader systems taps into a long-running debate in the social sciences about the primacy of leadership versus 
nondirected, iterative change in causing systemic shifts (Emirbayer and Mische 1998). The literature on SES straddles this divide. It contains forceful arguments that complex socialecological systems cannot be governed by the top-down, command and control forms of management sometimes associated with conventional ideas of leadership (Wheatley 1994, Gunderson et al. 1995, Holling and Meffe 1996, Greenleaf 2002). At the same time, SES research contains case studies showing strong evidence of the role of individual agency in achieving transformations from less adaptive to more adaptive management and governance systems (Olsson et al. 2006). This incongruity, in which one set of observations suggests that conventional leadership of SES is ineffectual and another identifies agency as a crucial factor in transformations for adaptability, suggests a new framework is needed to explain the role of agency in SES transformation.

In the literature, the individuals who "make it happen" have been identified variously as champions (Gilmour et al. 1999, Napier et al. 2005, Stankey et al. 2005), policy entrepreneurs (Shannon 1991, Huitema and Meijerink 2009), facilitators (Vasseur et al. 1997), dedicated energetic individuals (Wondolleck and Yaffee 2000), change agents (Crawford et al. 2006), organizational entrepreneurs (Hahn et al. 2006), brokers (Bebbington 1997), knowledgeable individuals or stewards (Olsson and Folke 2001), social innovators (Westley et al. 2006), and transformative or visionary leaders (Leach 2001, Westley 2002, Olsson et al. 2004, 2007). Ultimately, it is questionable whether leadership is the appropriate word for the activity of change agents in such a complex domain of networks, sectors, and scales. Drawing on a set of case studies, Folke et al. (2003) tested this assumption in SES, and identified numerous actor groups engaged in their stewardship: knowledge carriers and retainers, stewards and leaders, interpreters and sense makers, networkers and facilitators, visionaries and inspirers, innovators and experimenters, and followers and reinforcers. These change agents demonstrate a variety of skills seemingly required for transforming such complex, linked systems (Table 1).

The findings from the field of ecosystem stewardship are echoed in the small but growing body of work in management and organizational studies concerned with the role of strategic agency in complex and interorganizational domains (Westley et al. 2006, Plowman et al. 2007). Like the SES literature, this research explores agency at the broad system scale, in what might be termed the "problem domain" (Trist 1983, Westley and Vredenburg 1997). A problem domain is made up of the actors, organizations, and institutions concerned with or affected by a particular complex problem, and thus includes actors working at different organizational, jurisdictional, and geographic scales. When exploring the transformation of ecosystem management, the problem domain involves the local communities, management agencies, NGOs, corporations, government actors, indigenous groups, scientists, and actors who are invested in the future of that ecosystem, and provides a useful term to describe the social aspect of an SES.

The literature on agency in such problem domains argues that strategic agency is pivotal in moving a process of transformation forward (Westley 2002). Within complex problem domains, however, strategic agency is typically not associated with just one individual, rather is produced through the strategies of a number of actors, each of whom takes actions that help the system progress through different stages of innovation and transformation (Garud and Karnoe 2005, Hahn et al. 2006). This kind of effort is more precisely defined as "institutional entrepreneurship," a concept developed first by DiMaggio (1988) to describe the efforts of individuals who seek to change the institutions governing a particular domain in the interests of realizing particular goals of their own.

Shifting from the notion of leader to that of entrepreneur usefully moves the focus from the leader-follower relationship to the endeavor itself, and to the imperative of seizing opportunities and mobilizing resources that will gain support for innovations critical to transformations of social-ecological systems. Similarly, shifting the focus to the institutional level from that of the organizational leader allows us to see the importance of cross-scale interactions and of the challenge of transforming the value system, economic system, and political system that supports nonsustainable approaches to ecosystem stewardship. This focus is more in keeping with our understanding of emergence and change in complex adaptive systems (Westley et al. 2006). We will therefore refer to institutional entrepreneurs in our discussion of agency for transformation in complex social-ecological systems.

\section{INSTITUTIONAL ENTREPRENEURSHIP: MATCHING STRATEGIES TO OPPORTUNITY CONTEXTS AND THE ADAPTIVE CYCLE}

Various published studies have highlighted the skills and competencies needed to operate in complex adaptive systems (Zimmerman et al. 1998, Folke et al. 2003, Westley et al. 2006). Successful change agents in complex systems work to change beliefs, in particular, by convening all stakeholders around a common vision, change the flow of political authority and resources, in particular, by playing key roles in networks and mobilizing social capital, and challenge technical and legal frameworks, in particular, by encouraging integration of local knowledge, experimentation, and new scientific frameworks. When institutional entrepreneurs are successful in creating system-level disturbance, they exercise distinctive system-level capabilities, including the capacity to "see" the system and its dynamics, and to identify emerging windows of opportunity. An institutional entrepreneur may seek to shift dominant social norms and rules (Fligstein and Mara-Drita 1996, Zimmerman and Zeitz 2002), institutional logics, beliefs, and meanings (Creed et al. 2002, Garud et al. 2002, Suddaby and Greenwood 2005), and structures of power and 
Table 1. A review of the literature on skills involved in successful ecosystem stewardship.

\begin{tabular}{lll}
\hline \hline Strategies and methods & Description & References \\
\hline $\begin{array}{l}\text { 1) Facilitating knowledge } \\
\text { building and utilization }\end{array}$ & Building/enhancing knowledge of the ecological resources. & Crona and Bodin 2006, Bodin and Crona 2008 \\
& Generate and integrate a diversity of ideas, viewpoints, and solutions. & $\begin{array}{l}\text { Imperial and Kauneckis 2003, Marton-Lefèvre } \\
\text { and Mehers 2007, Westley and Vredenburg 1997 }\end{array}$ \\
& $\begin{array}{l}\text { Promote and steward experimentation at smaller scales (cf. active } \\
\text { adaptive management). }\end{array}$ & $\begin{array}{l}\text { Westley 2001, Olsson et al. 2006, Gunderson } \\
\text { and Light 2006 }\end{array}$ \\
& Catalyze community awareness and social learning. & Stephenson 2010 \\
& Conduct research, spread alternative ideas and knowledge & Font and Subirats 2010, Huitema and Meijerink \\
& & 2010
\end{tabular}

2) Vision building

3) Developing social networks
Provide a common vision that attracts a diversity of supporters upon which all can agree.

Creating new "social imaginaries" / create community cohesion accross a set of macro level shared aspirations.

Westley and Mintzberg 1989, Folke et al. 2003, Olsson et al. 2004, Olsson et al. 2007, Biggs et al. 2010

Stephenson 2010

Bridge different and similar actors and stakeholders across and within Westley and Vredenburg 1997, Woolcock and organizational hierarchies and types. This could be divided into three Narayan 2000, Olsson et al. 2004, Ernstson subcategories:

- Bonding, i.e., link with similar others. For example, establish local fishing organizations, knowledge exchange among local villagers, etc.

- Bridging, i.e., bring together similar and/or different groups to create momentum, gain support, and to react to various challenges. This could be called horizontal linking.

- Linking, i.e., communicate and engage with key individuals in different sectors, and to link across scales.

Create and protect safe spaces for interaction.

Seek ways to bring all parties to respect the perspectives of all sides. Stephenson 2010

Create opportunities for stakeholder involvement in management and Franzen et al. 2011 research.

Building multiactor and multilayered coalitions with a borad range of social organizations.

4) Building trust, legitimacy, and Developing networks (bonding/bridging/linking social capital). social capital

\section{Recognition of management initiatives by formal authorities.} Building consensus on rule compliance and representing stakeholder heterogeneity.

Mediating between organizations and the broader 'public.'

5) Facilitating / developing (social) innovations

6) Preparation, mobilization for change

7) Recognize or create and seize windows of opportunity
Identification and introduction of new alternatives, processes, products, and options, and of new ways to conduct businesses. Fostering knowledge building and innovations by bringing together different kinds of thinking.

Prepare the system to be able to effectively take advantage of forthcoming opportunities for change (windows of opportunity), including:

- raising awareness of a resource challenge

- leveraging limited resources and find new sources of funding

- building vertical social capital to influence policy decisions

- linking innovative ideas to resource opportunities ("management up-down")

Timing when to connect and mobilize others, i.e. creating the right links at the right time around the right issues.
2008, Olsson et al 2006, 2007, Manring 2007,

Biggs et al. 2010

Font and Subirats 2010, Huitema and Meijerink 2010, Meijerink and Huitema 2010

Hahn et al. 2006, Fell 2008, Bodin and Crona 2008, Biggs et al. 2010

cf. Ostrom 1990

Stephenson 2010

Westley et al. 2006, Westley 1990, Bodin and Crona 2008

Huitema and Meijerink 2010

Bainbridge et al. 2000, Danter et al. 2000, Olsson et al. 2004, 2006, 2008, Westley et al. 2006, Gunderson and Light 2006, Pahl-Wostl 2007

Westley 2002, Olsson et al. 2004, 2006, 2008, Gunderson and Light 2006 
Willingness to take risks and convince others to take risks. Venue shopping: pitching right idea to right organization.
Huitema and Meijerink 2010

Font and Subirats 2010, Meijerink and Huitema 2010, Wilder 2010

Ostrom 1990, Hahn et al 2006, Wondolleck and Yaffee 2000

communicating opportunities for actors involved can agree.

"small wins"?

Reconceptualize issues. Able to take a whole system perspective, find leverage points in system.

9) Facilitate conflict resolution and negotiations

Fair and low cost conflict resolution
Imperial and Kauneckis 2003, Hahn et al 2006,

Westley 2002

Sudtongkong and Webb 2008 resources (Lawrence 1999), sometimes replacing these with entirely new ones (Dacin et al. 2002, Maguire et al. 2004). This means engaging and managing the emerging energy of the system, both the formal power of the status quo and the power inherent in a desire for change, and at the same time maintaining a sense of the possible in the face of the perils of success or failure (Westley et al. 2006). Because success cannot be achieved through command and control (Holling and Meffe 1996, Goldstein et al. 2008), it must be realized through a deft mobilization of energy, i.e., choosing the right time and place, working through networks and partnerships, and connecting resources and opportunities to create social tipping points (Gladwell 2000, Padgett and McLean 2006).

In the literature on institutional entrepreneurship, the capacities for sensemaking and inspirational discourse have received particular attention (Battilana et al. 2009). Some have emphasized cultural skills such as visioning, marketing, framing, and motivating, as well as the ability to define the concerns and interests of constituencies, diagnose cases, assign blame, provide solutions, and enable collective attribution (Rao 1998, Perkmann and Spicer 2007). Others have echoed findings of those interested in diffuse or collective entrepreneurship, emphasizing the political and interactional skills of institutional entrepreneurs (Meijerink and Huitema 2010). These include incentivizing, coalition forming, bargaining, mobilizing, and leveraging resources for their projects (DiMaggio 1998), as well as the agenda setting, bargaining, and brokering skills that are key to achieving change in a policy arena (Fligstein 1997). Finally, some scholars have focused on the skills needed to establish new technologies, laws or protocols, i.e., structures of legitimation, including abstract categories and the formulation of patterned relationships such as chains of cause and effect (Strang and Meyer 1993).

This wide variety of skills identified in both the natural resource management literature and the literature on institutional entrepreneurs makes best sense when linked to strategies, and the strategies make best sense when linked to context. However, the literature is weakest in the area of linking "characteristics of the social environments as well as the actors' position within it" to the effectiveness of the institutional entrepreneur and calls for "a consistent typology of organizational fields" (Battilana et al. 2009:88). A key insight from the work on institutional entrepreneurship in complex problem domains is the suggestion that IEs respond to opportunities and resource flows in the system they inhabit. Their sensitivity to the dynamics of their own systems allows them to work in concert with these, rather than attempt to force a direction or outcome on the system. This is sometimes termed "managing for emergence," and has been the primary focus of literature on complexity leadership (Plowman et al. 2007, Uhl-Bien et al. 2007, Lichtenstein and Plowman 2009). Agents managing for emergence must stay tuned to context and to relationships. Indeed, it is against the unfolding background of what Osborn and Hunt (2007) call a "fitness landscape" that the effectiveness of institutional entrepreneurship and its associated skills must be described and evaluated. The challenge is to determine which contexts require which skills.

\section{Understanding skills and strategies in context: the adaptive cycle as opportunity context}

In complex SES, innovation, adaptation, and transformation are seen as ongoing requirements of resilient systems (Gunderson and Holling 2002, Folke 2006). In a seminal work that shaped the resilience paradigm in social-ecological analysis, Holling (1986) outlined a heuristic model, which he called the adaptive cycle (Fig. 1). It consists of an infinity loop powered by two drivers: the degree to which capital or potential in the system is either stored or released, and the degree to which the system is either homogenous or heterogeneous in certain features, i.e., connectedness. These drivers frame the four phases of the adaptive cycle: exploitation, conservation, release, and reorganization. Although this model was initially created based on an understanding of the dynamics of resilient ecosystems, it also functions to illuminate the dynamics of resilient social systems and the role of innovation in this dynamic: creative destruction when old ideas and routines collapse; exploration, when new ideas are developed; launch when successful ideas are supported by investment of new capital; and institutionalization, when the innovation becomes an established part of our day to day life. Understanding SES involves being attuned to the 
different phases of the cycle and understanding the processes and dynamics that characterize each phase. The "back loop" of the cycle is the turbulent change arena in which innovation and novelty can emerge. Such novelty can feed adaptation and build resilience of the broader system, or it can trigger a transformation of the broader institutional system, pushing it into a new configuration or stability landscape, new physical and institutional structures, and a new "front loop" (Gunderson and Holling 2002, Walker et al. 2004, Folke et al. 2010). We are interested in the agency that enables the latter, i.e., a transformation toward ecosystem stewardship, which represents a new "front loop" and ultimately reconnects people to the biosphere (Fig. 2; Chapin et al. 2010, Westley et al. 2011). In line with this, we suggest that previous work on social-ecological transformations has identified such agency in the front loop of the previous cycle, "preparing for change," as well as in the back loop, "navigating the transition," and in the front loop of the new cycle, "building resilience of the new regime" (Olsson et al. 2004).

Fig. 1. The adaptive cycle. Source: Adapted from Holling (1986)

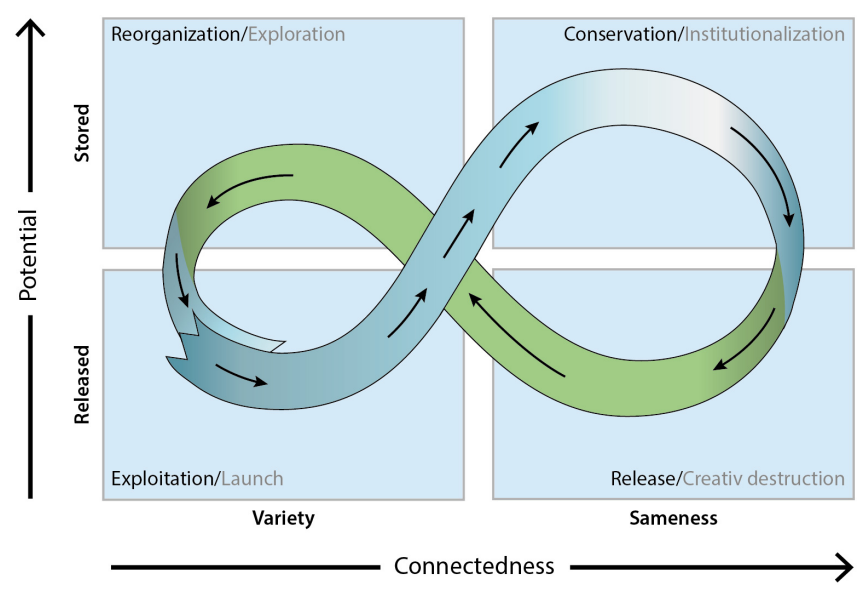

The different phases of the adaptive cycle present a type of fitness landscape in which institutional entrepreneurs working with SES must orient themselves. No matter how skillful, the IE must also be able to see the opportunities presented by the changing landscape of the system to advance the desired transformation. What is the nature of these opportunities?

Few scholars have thought through the relationship between agency for change, the need to mobilize resources, and the quality of opportunity as clearly as Dorado (2005). Drawing on the work of social movement scholars (McAdam 1996, Tarrow 1996), Dorado has explored her notion of the opportunity context. Within the social movement literature, it has been argued that the emergence of new social movements depends on taking advantage of openings in political systems
Fig. 2. A model of agency, context, and problem domain innovation and the shift to a new configuration of the socialecological system. 1a,b) Institutionalizing innovation. 2a,b) Releasing resources for innovation. 3) Stimulating emerging innovations and partnerships.

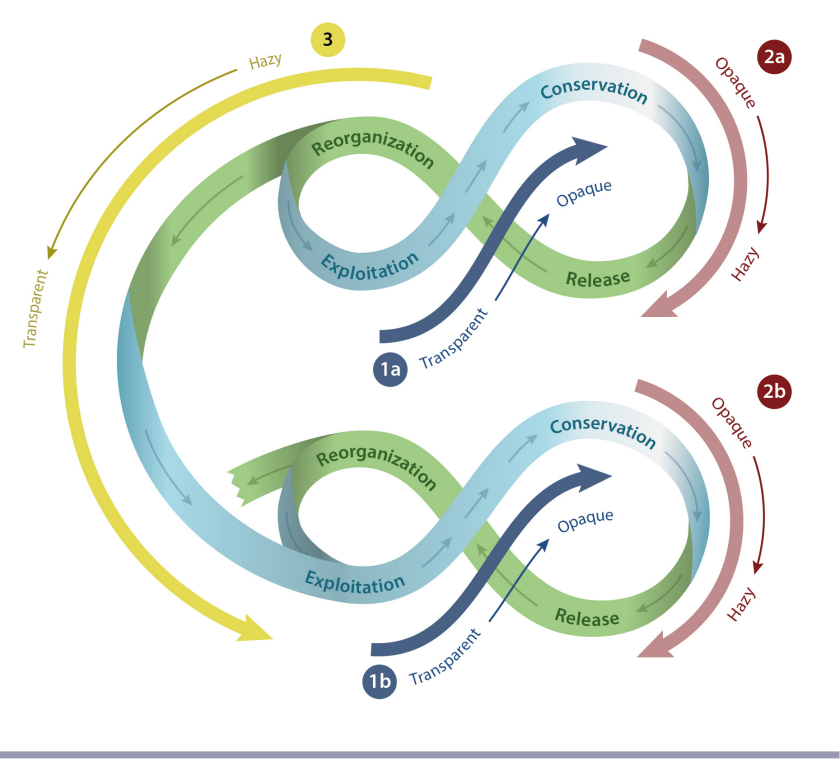

that arise from changes in formal or informal political institutions, and on mobilizing resources and collective action (McAdam et al. 1996). Dorado has adapted this notion of political opportunity to look at social innovation. She defines opportunity as "the likelihood that an organizational field will permit actors to identify and introduce novel institutional combinations and facilitate the mobilization of resources required to make it enduring" (Dorado 2005:113), and suggests that it can be opaque, transparent, or hazy.

Dorado joins other scholars of institutional entrepreneurship (Battilana et al. 2009) in identifying two primary drivers of opportunity context: the diversity and multiplicity of organizational forms, and the degrees of institutionalization. A multiplicity of organizational forms implies that there are many different and overlapping organizations within the problem domain, each with its own access points and processes that IEs can take advantage of to mobilize action and resources in support of their innovation. However when multiplicity is too great, resources may be fragmented and difficult to amass in large quantities. When multiplicity is absent, IEs may be unable to find or access the resources necessary for their innovation to gain traction. The degree of institutionalization refers to the extent to which institutions govern social behavior. When there is little institutionalization, behavior is unpredictable and actors in the system may be hesitant and unwilling to take risks. When institutionalization is very high, 
behavior is taken for granted and actors are unlikely to welcome or see the need for innovation. It is interesting to note the similarities between Dorado's set of drivers, multiplicity and institutionalization, and those of Holling's adaptive cycle, homogeneity/heterogeneity and stored/released capital, because from the point of view of agency, both concern the ability of actors to access resources for new initiatives and to find points in the system in which there is enough leeway to introduce novelty.

Problem domains that are characterized as transparent have a multiplicity and diversity of organizational forms that are loosely coupled and governed by norms and beliefs that are not completely institutionalized, allowing for "the display of tensions [which] favor the development of new arrangements" (Dorado 2005:26). Dorado suggests that much of what we identify as entrepreneurial is associated with such contexts. In opaque contexts, there are few dominant organizations, and they are fully institutionalized, resulting in much more constrained opportunities for novelty or innovation. This is consistent with the findings of a number of scholars who agree that mature or stable contexts, with broadly coherent sets of rules, offer fewer opportunities for the creation or introduction of novelty and change than declining or crisis ridden contexts (Fligstein 1997, Perkmann and Spicer 2007). Finally, in situations in which there are few organizational or institutional forms, such as after a major political transition or an unexpected natural disaster, opportunities could be called hazy. Such contexts are characterized by tension and unpredictability, in which actors and organizations may be open to novel ideas and relationships, but uncertainty over the future makes it difficult to act strategically, and fragmentation makes it difficult to mobilize sufficient resources to support innovative or ambitious projects. In these contexts, there must be enough institutional reorganization to provide the basic consensus on meaning and values required to mobilize resources of capital and imagination, and to build organizational linkages (Erikson, 1995). Sometimes such new consensus can be built on a shadow system, which has been cultivated and is waiting for just such an opportunity. An example is the transformation of Chile's coastal marine resources, in which an alternate framework for resource management was cultivated by a shadow network of scientists and activists, but provided a platform for radical shift from individual to community fishing regimes when political upheaval, i.e., the end of the Pinochet regime, provided a release of resources (Gelcich et al. 2010)

We argue that the opportunity context of an SES is not static, rather it is dynamic and changes as the system moves through different phases of a transformation, in the manner suggested by the adaptive cycle (see also Tarrow 1996 for dynamics of political opportunities). By superimposing Dorado's concept of opportunity contexts on the phases of change in the adaptive cycle, we can create a new heuristic to help us understand the dynamics of institutional entrepreneurship in an SES undergoing change (Fig. 2, Table 2). The adaptive cycle's back loop of turbulent change, and front loop of more gradual, routine change both present challenges to institutional entrepreneurs, but of different kinds. At the same time, the transition from back to front loops will have an impact on the multiplicity of organizational forms and the degree of institutionalization of the domain. Crucially, we argue that successful transformation will only occur if IEs tailor their actions to the specific characteristics and opportunities of each phase of change. Although previous work, including Plowman et al. (2007) and Olsson et al. (2004), has developed a similar notion of distinct phases in a transformation process requiring particular responses, we wish to add further nuance and a better sense of the affinity of particular skills and strategies to different phases. By connecting certain types of entrepreneurial activities to phases of change, we can improve our understanding of the specific strategic aims of these activities and their impact on the overall process, including their impact on the process of transformations in SES. We also gain a context for deciphering the competencies and strategies identified in the literature on agency in complex problem domains surveyed above (Table 1; see also Folke et al. 2003, Westley et al. 2006).

\section{Catalyzing change in complex social-ecological systems: context and strategy}

\section{Fostering release in the move from opaque to hazy opportunity context}

In opaque opportunity contexts, innovation is very unlikely to occur. Opaque opportunity contexts are by definition "mature." In Holling's (1986) terms, they correspond to the conservation phase, and exhibit the same features of homogeneity and high stored capital. This is not a favorable opportunity context for the introduction of novelty. In fact, most actors in mature systems are likely to actively resist change (Embirayer and Mische 1998) and prefer to maintain a stable and predictable environment constituted by the existing institutional context. The existing institutions and resource flows must be disrupted and challenged to provide the room and the fuel for innovation.

Transformational agents and institutional entrepreneurs working in opaque contexts may act to create disturbances. For example, on Canada's west coast, a major regional transformation to ecosystem-based management began with considerable conflict. In what has come to be known as the Great Bear Rainforest (GBRF) case, the scientific argument for conservation did not gain much traction among the governing authorities. Instead, the ENGOs mobilized other resources to disrupt logging operations. This process was begun on Clayoquot Sound where loggers, protesters, and law enforcement fell into bitter stand offs and was continued on the central coast through a market campaign that targeted 
Table 2. Comparing models of context dynamics and agency.

\begin{tabular}{ll}
\hline \hline Opportunity contexts & Opaque - Hazy \\
After Dorado (2005) & A few organizations dominate. \\
& Institutions and beliefs are well \\
& established. As challenges to the \\
& established order emerge, the contex \\
& moves from opaque to hazy.
\end{tabular}

Associated ways of mobilizing support for change

After Dorado (2005)

Associated agency

After Dorado (2005)

Phases of social-ecological transformations

After Olsson et al. (2004)

Phases of change in complex adaptive systems

After Holling (1986)
Accumulation

Accumulation implies that support and acceptance of new institutions emerge as the uncoordinated actions of countless actors probabilistically converge.

\section{Routine, Strategic \\ Routine agency involves re-enacting of past patterns of behavior and thus brings stability to institutional fields. Strategic agency involves actors defining their valued interests and deciding on a particular course of action to serve them.}

\section{Preparing for transformation} Agents build ecological knowledge, develop a shared vision, and expand their social network.

Hazy - Transparent
Old organizations lose their
dominance. Institutions and beliefs
are open to reinterpretation. As new
organizations and understandings
emerge, the context becomes
transparent.

Accumulation, Convening, and

Leverage

Convening means bringing actors "to the table," not to convince them of a predefined way forward, but to work together.

Routine, Sense-making, Strategic

Sense-making involves developing a coherent story that helps actors deal with a problematic present.

Navigating the transition

Agents use a window-of-opportunity to create a new governance system.

\begin{abstract}
Transparent - Opaque
Multiple organizations that are

loosely coupled are present, and many different beliefs coexist. As some of these disappear and others become more tightly coupled, the context becomes opaque again.
\end{abstract}

Leverage, Accumulation Leverage means that politically skilled actors mobilize support and acceptance for certain ideas.

\section{Strategic, Routine}

Strategic agency involves actors defining their valued interests and deciding on a particular course of action to serve them.
Conservation-Release Biomass and nutrients have accumulated and a few species dominate. Disturbances such as wildfires release these resources.
Release - Reorganization Exploitation

Pioneer species that are able to make use of the released energy enter.

Others follow, and the ecosystem is reorganized. international buyers of GBRF wood and managed to lead to the cancellation of several large contracts. Such actions created tension in the social system, but had enough impact on the market and on the media that the premier of British Columbia, who had branded the environmentalist enemies of the state, was prepared to seek collaborative solutions, as were the large timber companies. Groups were divided at this stage into interest factions, promoting their agendas with little sign of willingness to negotiate or even understand the agendas of others (Riddell et al. 2012)

In other cases, institutional entrepreneurs wait for those disturbances to occur through external or internal shocks to the system. Institutional entrepreneurs can make headway by employing strategies such as identifying openings, mobilizing resources, and recognizing and stimulating innovations in the form of routine adaptation. These are all ways of preparing the ground (Olsson et al. 2004). Dorado describes this activity as "accumulation," in which resources are gathered in preparation for an opportunity to introduce novelty into the system. Moreover, as Uhl-Bien et al. (2007) suggest, agents need to be attuned to the system so that they can identify emerging windows of opportunity as quickly as possible. In effect, IEs are alert for learning moments, small wins, and serendipity (Weick and Westley 1996) to continue to promote innovation despite the inherent rigidities in such opaque opportunity contexts.

However, as the adaptive cycle suggests, in complex systems shocks will inevitably occur. They may be externally driven, for example by weather events or by financial crises, or they may be internal, such as overfishing leading to a collapse of stocks, or a political crisis leading to the collapse of a government. Institutional entrepreneurs may work in the background, preparing alternative innovation regimes that can serve as a starting point when the opportunity context shifts to hazy. For example, in the Great Barrier Reef (GBR) in Australia, problems like increased outbreaks of crown of thorns starfish triggered scientists, in particular at James Cook University and the Australian Institute of Marine Science, to 
gather information from the 1970s onward, which showed that despite the existence of the marine park, the reef was under stress (Olsson et al. 2008). Those who have best anticipated and prepared for the shock can take quick advantage of the opening.

Fostering sensemaking for experimentation in the transition from hazy to transparent opportunity context

Shocks, whether ecological, political, economic, or social, can lead individuals to question existing institutional arrangements and may introduce "meaning vacuums" into social systems. These are typical of the release phase of the adaptive cycle, in which a perception of crisis undermines the rules, meanings, and authority systems on which earlier stages relied. This presents a hazy opportunity context for innovation; it calls for heightened communication and interaction before resources of ingenuity, creativity, or effort are mobilized for action or change, which Dorado (2005) refers to as convening, and Lichtenstein and Plowman (2009) characterize as embracing uncertainty and supporting collective action. For this reason, transformational agents at this point often connect with actors in the system and engage in various forms of sensemaking, either participatory, through whole system processes such as scenario planning or future search, or through a synthesis of various types of data, such as mapping exercises.

For example, the Kristianstads Vattenrike (KV) Biosphere Reserve has been shaped during millennia by agricultural practices in combination with the annual flooding of the Helgeå River. Continuous livestock grazing and mowing for haymaking have resulted in a landscape with unique values, biological as well as cultural-historical. Over the last three centuries, the hydrology has been altered by draining, dredging, and the building of embankments, mainly to gain land for cultivation and city expansion, and the wetlands have shrunk accordingly. During the 1960s, wetlands were largely seen as wastelands. The municipal public health committee stated that "these water-infested and unhealthy swamps need to be dredged," and the city dump was established on the wetlands (Magnusson 2004:324).

In 1975, an attempt was made by the Swedish Environmental Protection Agency (EPA) to secure the biological values of the remaining flooded meadows. Two key actors emerged in this phase who continued to be important throughout the transformation. The first was Hans Cronert at the Bird Society of Northeastern Scania, who worked to improve understanding of the wetland ecosystem dynamics by documenting declining waterfowl populations and linking them to the decline in traditional agricultural practices. The second was Sven-Erik Magnusson at the County Museum, who worked to enhance the understanding among decision makers and the public of the links between culture and nature in Kristianstad. Together, these two actors embarked on an exercise to thoroughly map historical and present-day land use practices, creating a system wide picture of Kristianstad.

Using the County Museum as a platform, Magnusson took steps to disseminate his understanding of the ecosystem through a series of exhibitions linking traditional land use practices to the values of the ecosystem. In so doing, he gave new meaning to the wetlands as water rich rather than "water sick." Reinforcing this idea was the name that became attached to the wetlands, Kristianstads Vattenrike, which carries the double meaning in Swedish of both water kingdom and water riches.

In addition to sensemaking, IEs in this phase work to build early partnerships between stakeholders through intensive communication, some of it one on one. In KV Sweden, Magnusson conducted a number of one-to-one meetings with key stakeholders to identify mutual interests connected to the restoration of wetlands (Hahn et al. 2006). In the Great Bear Rainforest in Canada, activists worked to convene all parties, reduce hostilities, and encourage partnerships.

Gradually, this communicative activity results in the emergence of new collaborations between actors and organizations working toward common goals and deploying their resources in support of novel endeavors. As these projects mature and new resource flows become available, the opportunity context grows increasingly transparent. This might come closest to the period known as "letting a thousand flowers bloom" often associated with broad social innovation (Westley et al. 2006) in which a multiplicity of new innovations proliferate throughout the system, creating many new opportunities for IEs.

\section{Fostering exploitation and accumulation in the move from transparent to opaque opportunity context}

The transparent opportunity context is one of intense activity. As they pilot this phase, the transformational agents may not yet have a clear idea of what the final strategy or initiative will look like. It is a highly exploratory and experimental moment. They are challenged to continue to build networks, identify possible partnerships, broker these, and try to secure resources. Key to this phase is the recombination of resources in new forms (Lichtenstein and Plowman 2009). New combinations present huge potential for novelty and for the emergence of self-organized behavior that can be supported and amplified (Plowman et al. 2007).

By providing a focus to the entrepreneurial activities of the increasingly transparent opportunity context, umbrella projects can be seen as a continuation of the sensemaking and convening described above. When first conceived, these projects do not in themselves provide the answers to all of the problems facing the SES, but they create a bundle of knowledge, meaning, and vision that is open ended enough to attract different interest groups with their different concerns, 
and to allow them to work collaboratively on a common project. Within the Great Barrier Reef Marine Park (GBRMPA) a unifying idea was taking shape as a small group in the organization realized that one way to simultaneously fulfill all of the organization's different aims was to embark on an ambitious project to rezone the entire reef using the representative areas program. This project eventually came to encompass more and more of the activities of the organization and became a focus for its resources. In KV Sweden, the Ecomuseum Kristianstads Vattenrike (EKV) idea played a similar role, and in the GBRF Canada, the umbrella solution that emerged was not so much a coherent whole as a package of ideas known as the five-point agreement.

The five-point agreement encompassed the different aims and concerns of the various stakeholders. It included a plan to manage the forests using ecosystem-based management (EBM) principles, the establishment of First Nations as equal partners with government through the commitment to government-to-government negotiations, a package of economic development to make the region less dependent on resource extraction, the establishment of a multiparty scientific panel with representatives of all of the major stakeholder groups, and a commitment to more protected areas.

In all three of these examples, the establishment of these umbrella projects can be seen as a breakthrough in the transformational change process because they mark an end to unfettered innovation, and the rising importance of more focused and strategic agency, aimed at securing resources and support for these projects.

In the transparent opportunity context, competition for resources is intense. Not all of the ideas generated in the previous phases can become fully fledged innovations, and those that do need to attract sufficient resources and support to grow and come to fruition. In this context, agents need to know where to find and how to attract capital of all kinds. They need to act strategically to ensure that their innovation survives this phase as the system moves into another period of stability when opportunities for change will once again be few. Agents work to formalize their innovations and enshrine them in new institutions. In the GBR Australia and GBRF Canada new laws were created, and in KV Sweden agents have secured international recognition of the change they created.

Leveraging resources is the act of attaching them to a particular innovation. Agents who successfully move through a transparent opportunity context stage show a deft strategic ability to identify and win over potential key supporters and funders. In the GBR Australia, the small group that had conceived the idea of a reef wide rezoning initiative gained the support of the executives. Soon after, almost all of the GBRMPA staff became involved in the rezoning project that had started with just a small group. Gaining the support of the executive team was crucial. They went on to help establish a senior managers' forum to coordinate activities, enhance communication, solve conflicts, tap into the expertise of senior managers to ensure a shared policy direction, and advise the organization's chair. Great Barrier Reef Marine Park used its organizational flexibility to establish and nurture a creative environment in which innovative solutions to problems could emerge. Importantly, this process was achieved without any additional funding and relied entirely on a flexible internal redeployment of staff. Critically important though, was their ability to target and attract the support of the Minister for the Environment, who was crucial in piloting the rezoning plan through the political process.

In the GBRF, one piece of the five-point agreement was critical, namely the Conservation Investments and Incentives Initiative (CIII) to attract 120 million dollars for sustainable economic development. By committing to this figure, the ENGOs were demonstrating to the First Nations and provincial government that they were committed to human as well as ecological well-being, but money had to be found. Private donations and large foundation donations provided 30 million dollars, 30 million from the province, and the rest was matched by the federal government of Canada. Without these material resources the agreement might never have got off the ground.

Ultimately, to achieve durability for the transformation, agents need to find ways of institutionalizing the change they have created. In Canada, following a provincial election, the institutional entrepreneurs involved faced a long hard fight to see the five-point agreement turned into new law, but they were aided in this fight by their new links to industry. In the GBR Australia, agents demonstrated the importance of strategically scanning the landscape to anticipate obstacles and opportunity and identified a small window of time for the rezoning plan to gain parliamentary approval and moved quickly to ensure that this happened before the federal election of July 2004. Finally, in KV Sweden, not only was the EKV established but Magnusson and his colleagues also sought, and were granted UNESCO biosphere reserve status for the whole area.

It is important to note that these forms of institutionalization do not necessarily mark the end of the transformation because early in the conservation phase there is still room for maneuvering and competition, but the scope for new ideas rapidly begins to narrow as resources become committed and tied up in ongoing work.

In Dorado's terms, institutional entrepreneurs at this point are likely to employ leveraging strategies aimed at capturing these resource flows and establishing new institutions to support their innovations. Entrepreneurial skills become paramount as the transformational agents leverage resources in an effort to connect the best ideas from the previous phase to political 
Table 3. Linking strategy, opportunity context, and innovation phase.

\begin{tabular}{|c|c|c|c|}
\hline Opportunity Context & Opaque to Hazy & Hazy to Transparent & Transparent to Opaque \\
\hline Adaptive Cycle Phase & Conservation to Release & $\begin{array}{l}\text { Release to Reorganization to } \\
\text { Exploitation }\end{array}$ & Exploitation to Conservation \\
\hline \multirow[t]{3}{*}{$\begin{array}{l}\text { Corresponding Institutional } \\
\text { Entrepreneur Strategies }\end{array}$} & $\begin{array}{l}\text { Introducing disturbances to } \\
\text { stimulate the release of resources } \\
\text { and lower the resilience of the } \\
\text { dominant regime. }\end{array}$ & $\begin{array}{l}\text { Encouraging the proliferation of } \\
\text { ideas and the recombination of } \\
\text { resources in new and novel forms } \\
\text { by, e.g., building networks, making } \\
\text { room for emergent self } \\
\text { organization. }\end{array}$ & $\begin{array}{l}\text { Leveraging economic, social, and } \\
\text { ecological resources to support best } \\
\text { innovative ideas, and integrating these into } \\
\text { existing institutional context. }\end{array}$ \\
\hline & $\begin{array}{l}\text { Convening activities such as } \\
\text { sensemaking and sensegiving to } \\
\text { support collective action; } \\
\text { encouraging stakeholder } \\
\text { participation. }\end{array}$ & $\begin{array}{l}\text { Allowing for a dominant design to } \\
\text { emerge by encouraging the } \\
\text { dropping off of unpromising ideas } \\
\text { and linking those that offer a viable } \\
\text { alternative platform. }\end{array}$ & $\begin{array}{l}\text { Continuing to support adaptive } \\
\text { modifications and accumulate resources } \\
\text { for small wins that build the resilience of } \\
\text { the new institutional context. }\end{array}$ \\
\hline & $\begin{array}{l}\text { Resource mobilization through } \\
\text { sensemaking and convening. }\end{array}$ & $\begin{array}{l}\text { Resource mobilization through } \\
\text { leveraging and brokering. }\end{array}$ & $\begin{array}{l}\text { Resource mobilization through } \\
\text { accumulation. }\end{array}$ \\
\hline Skills employed & $\begin{array}{l}\text { Cultural skills: visioning, } \\
\text { marketing, framing, motivating, } \\
\text { and defining; enabling collective } \\
\text { attribution. }\end{array}$ & $\begin{array}{l}\text { Leveraging and Brokering skills: } \\
\text { identifying windows of } \\
\text { opportunity, engaging the emerging } \\
\text { energy of the system, working } \\
\text { through networks and partnerships, } \\
\text { connecting ideas and resources. }\end{array}$ & $\begin{array}{l}\text { Political-Interactional skills: incentivizing, } \\
\text { coalition forming, bargaining, mobilizing, } \\
\text { and leveraging resources. }\end{array}$ \\
\hline Agency identified as: & $\begin{array}{l}\text { Knowledge carriers and stewards, } \\
\text { sense makers and interpreters, } \\
\text { visionaries, and inspirers. }\end{array}$ & $\begin{array}{l}\text { Innovators and experimenters, } \\
\text { brokers, facilitators. }\end{array}$ & $\begin{array}{l}\text { Followers and reinforcers, policy } \\
\text { entrepreneurs, champions, advocates, } \\
\text { organizers. }\end{array}$ \\
\hline
\end{tabular}

opportunity and sources of financing. Viewed in terms of the adaptive cycle, this phase occurs as one moves through the back loop into the reorganization phase of reconstituting the direction of the current system, or shifting pathways into a new system (Fig. 2). Olsson et al. (2008) characterize this period of activity as "navigating the transition." At this point, although the opportunity context remains transparent, with a diversity of players and elements available for realignment, the transformational agents shift gears from the experimental to the political.

While the transformational agents continue to leverage resources and exploit political, economic, and cultural opportunities, a new order is being firmed up in which the innovation becomes "business as usual." The innovation needs to establish itself within the system and position itself in relation to existing institutions, "integrating local constraints" in the language of Lichtenstein and Plowman (2009). This begins a "stabilizing sequence" (Plowman et al. 2007) in which the opportunity context once again becomes opaque because resources available for innovation are channeled into establishing a new mature system.

With the introduction of the notion of opportunity contexts, we can see that the long and seemingly chaotic list of capabilities, attributes, skills, and strategies associated in the literature with transformative agency and institutional entrepreneurship in complex systems (summarized in Table 3 ), in fact, has coherence. Skilled institutional entrepreneurs may employ different skills at different points, or they may pass the initiative on to other individuals with the skills appropriate to the contextual demands of a particular phase. The need to respond appropriately to the phase-specific demands creates a wide variety of strategies that are appropriate, meaningful, and effective in a particular context. Overall, each phase is important in the transformation of a system, and each strategy plays a role in facilitating the shift.

\section{SUMMARY, CONCLUSIONS, AND SUGGESTIONS FOR FURTHER STUDY}

Individual agency has an important role to play in shifting from top down to more flexible and integrated approaches to managing and governing natural resources and ecosystem services. Research shows that there are networks of individuals contributing in different ways to collectively navigate transformation. Leadership scholars have introduced the notion of institutional entrepreneurship, which reflects disaggregated and diffuse agency. Institutional entrepreneurs are highly sensitive to the context in which they work, and seek to guide, rather than commandeer, transformation using skills and strategies appropriate to this kind of agency. In SES, and particularly during a period of transformation, the system is constantly changing. Holling (1986) introduced the concept of the adaptive cycle to describe the way that SES move through processes of destruction and renewal, characterized in terms of the connectivity of the system and the amount of available resources. Similarly, Dorado (2005), an IE scholar, 
has suggested that IEs work in opportunity contexts that can be opaque, hazy, or transparent, depending on the availability of organizations to mobilize resources for collective action and the degree to which the institutional structures allow for innovation in the system. By combining these two heuristic methods it is possible to better understand the context in which agents in SES transformations work. Moreover, the literature suggests that certain types of strategies will be particularly appropriate to certain phases of change, and not to others. In summary:

1. As SES move through distinct phases of change described by the adaptive cycle, the opportunity context for introducing innovation into that system will shift. When seeking to transform complex social-ecological systems, agents will pursue strategies appropriate to each phase of the cycle.

2. In the conservation phase of the adaptive cycle, institutional structure will be established and become resistant to challenge and novelty, and there will be a paucity of organizational forms that IEs can utilize to build support and accumulate resources for change. In such opaque opportunity contexts, IEs will pursue strategies that involve anticipating, preparing for, and helping to create disturbances that free up resources and break down established institutions. To do so, they will accumulate small pockets of resources and support, preparing for the moment when a disturbance will create the transition from an opaque to a hazy opportunity context.

3. Following an internal or external shock, the SES will move from the conservation to the release phase. In the process, institutions may lose credibility or collapse, making room for novelty but leading to uncertainty about the future. Organizational forms will be fragmented and loosely connected to resources, hampering the ability to mobilize resources and the willingness to take risks necessary for social innovation. In this hazy opportunity context, IEs will employ convening and sensemaking strategies to bring organizations together to create common interpretations, meaningful narratives, visions, and goals that provide the platform and focal point for collective action and the flow of resources. Once such a platform is in place, IEs can begin to facilitate relationships between ideas, resources, and organizations in response to an increasingly transparent opportunity context.

4. As the system moves from the release phase to the reorganization and exploitation phases, new institutions will appear, but will still be in the process of establishing themselves, so that there is both flexibility and predictability required for ambitious projects. Although the opportunity context in both these phases can be described as transparent, the IE's emphasis is different in each. In the reorganization phase, new organizational forms and new linkages between them emerge, creating many opportunities for IEs to engage in "bricolage," connecting ideas and resources strategically through brokered partnerships. Institutional entrepreneurs will work to encourage the continued emergence of innovative ideas, but also to parlay partnerships into viable alternative configurations. Some ideas will inevitably be orphaned, but with successful brokering, resources may be consolidated around a coherent and innovative alternative. In the exploitation phase, IEs will focus on leveraging resources and political support for this more integrated set of ideas. In establishing the primacy of their innovation, IEs lay the groundwork for a new established institutional context. At the same time, the reduction in the multiplicity of organizational forms signals the arrival of a new stable conservation phase.

In sum, we suggest that agency in social-ecological transformation must act in concert with the evolving context of the system in question. However, this evolution is not random. Just as social-ecological systems experience the phase changes captured by the adaptive cycle, the opportunity context experienced by agents goes through familiar stages. We have presented an analytical framework designed to help highlight and clarify such connections. Based on a review of the literature, some preliminary suggestions are made about the way certain types of activities parallel different stages of a transformation process. These suggestions are based on theoretical considerations, as well as surveys of literature describing grounded research. They need to be tested and enriched by empirical investigation; nonetheless, they provide an agenda for further research on the role of agency in SES transformation.

More work is needed to understand in greater depth the pattern described by our analytical framework, and to identify the many ways that IEs mobilize the central skills of sensemaking, facilitating relationships, building partnerships, leveraging, and selling in particular opportunity contexts. There is great scope for studies that seek to add detail and nuance to the descriptions of convening, leveraging, and accumulating strategies for shifting social-ecological systems toward sustainable pathways of development. Moreover, studies should explore what happens when there is a lack of agency, or when actors follow strategies associated with some, but not all, of the stages, when we would predict that the transformation should fail to achieve desired outcomes. Questions may also be asked about which actors in the system are likely to be best positioned to pursue particular strategies, based on factors such as their access to different types of resources, their position within the system's social networks, and their access to power. Our aim is to encourage work of this sort that draws on insights from different fields about the 
role of agency in SES transformation, and our understanding of the vital impact that individuals can have in these processes.

Responses to this article can be read online at: http://www.ecologyandsociety.org/issues/responses. php/5072

\section{Acknowledgments:}

Support from Mistra through a core grant to the Stockholm Resilience Centre and from the J.W. McConnell Family Foundation through a core grant to the Waterloo Institute for Social Innovation and Resilience is gratefully acknowledged.

\section{LITERATURE CITED}

Bainbridge, V., S. Foerster, K. Pasteur, M. Pimbert, G. Pratt, and I. Y. Arroyo. 2000. Transforming bureaucracies: institutionalising participatory approaches and processes for natural resource management: an annotated bibliography. International Institute for Environment and Development, Institute of Development Studies, London, UK.

Battilana, J., B. Leca, and E. Boxenbaum. 2009. How actors change institutions: towards a theory of institutional entrepreneurship. Academy of Management Annals 3 (1):65-107. http://dx.doi.org/10.1080/19416520903053598

Bebbington, A. 1997. Social capital and rural intensification: local organizations and islands of sustainability in the rural Andes. Geographical Journal 163:189-197.

Biggs, R., F. R. Westley, and S. R. Carpenter. 2010. Navigating the back loop: fostering social innovation and transformation in ecosystem management. Ecology and Society 15(2): 9. [online] URL: http://www.ecologyandsociety. org/vol15/iss2/art9/

Bodin, Ö., and B. J. Crona. 2008. Management of natural resources at the community level: exploring the role of social capital and leadership in a rural fishing community. World Development 36(12):2763-2779. http://dx.doi.org/10.1016/j. worlddev.2007.12.002

Chapin, III, F. S., S. R. Carpenter, G. P. Kofinas, C. Folke, N. Abel, W. C. Clark, P. Olsson, D. M. S. Smith, B. Walker, O. R. Young, F. Berkes, R. Biggs, J. M. Grove, R. L. Naylor, E. Pinkerton, W. Steffen, and F. J. Swanson. 2010. Ecosystem stewardship: sustainability strategies for a rapidly changing planet. Trends in Ecology and Evolution 25(4):241-249. http:// dx.doi.org/10.1016/j.tree.2009.10.008

Crawford, B., M. Kasmidi, F. Korompis, and R. B. Pollnac. 2006. Factors influencing progress in establishing community-based marine protected areas in Indonesia.
Coastal Management 34:39-64. http://dx.doi.org/10.1080/0$\underline{8920750500379300}$

Creed, W. E., M. A. Scully, and J. R. Austin. 2002. Clothes make the person? The tailoring of legitimating accounts and the social construction of identity. Organization Science 13 (5):475-496. http://dx.doi.org/ 10.1287/orsc.13.5.475.7814

Crona, B. J., and Ö. Bodin. 2006. What you know is who you know? Communication patterns among resource users as a prerequisite for co-management. Ecology and Society 11(2): 7. [online] URL: http://www.ecologyandsociety.org/vol11/ iss2/art7/

Dacin, M. T., J. Goodstein, and W. R. Scott. 2002. Institutional theory and institutional change: introduction to the special research forum. Academy of Management Journal 45 (1):45-56. http://dx.doi.org/10.5465/AMJ.2002.6283388

Danter, K. J., D. L. Griest, G. W. Mullins, and E. Norland. 2000. Organizational change as a component of ecosystem management. Society and Natural Resources: an International Journal 13(6):537-547. http://dx.doi.org/10.1080/08941920050114592

DiMaggio, P. 1988. Interest and agency in institutional theory. Pages 3-22 in L. Zuker, editor. Institutional patterns and organizations: culture and environment. Ballinger, Cambridge, Massachusetts, USA.

Dorado, S. 2005. Institutional entrepreneurship, partaking, and convening. Organization Studies 26(3):385-414. http:// dx.doi.org/10.1177/0170840605050873

Emirbayer, M., and A. Mische. 1998. What is agency? American Journal of Sociology 103(4):962-1023. http://dx. doi.org/10.1086/231294

Ernstson, H. 2008. In Rhizomia: actors, networks, and resilience in urban landscapes. Dissertation. Stockholm University, Stockholm, Sweden.

Fell, T. P. 2008. Conflict and legitimacy: explaining tensions in Swedish hunting policy at the local level. Environmental Politics 17(1):105-114. http://dx.doi.org/10.1080/09644010$\underline{701811707}$

Fabricius, C., C. Folke, G. Cundill, and L. Schultz. 2007. Powerless spectators, coping actors, and adaptive comanagers: a synthesis of the role of communities in ecosystem management. Ecology and Society 12(1): 29. [online] URL: http://www.ecologyandsociety.org/vol12/iss1/art29/

Fligstein, N. 1997. Social skill and institutional theory. American Behavioral Scientist 40(4):397-405. http://dx.doi. org/10.1177/0002764297040004003

Fligstein, N., and I. Mara-Drita. 1996. How to make a market: reflections on the attempt to create a single market in the 
European Union. American Journal of Sociology 102(1):1-33. http://dx.doi.org/10.1086/230907

Folke, C. 2006. Resilience: the emergence of a perspective for social-ecological systems analyses. Global Environmental Change 16(3):253-267. http://dx.doi.org/10.1016/j.

gloenvcha.2006.04.002

Folke, C., S. R. Carpenter, B. Walker, M. Scheffer, T. Chapin, and J. Rockström. 2010. Resilience thinking: integrating resilience, adaptability and transformability. Ecology and Society 15(4): 20. [online] URL: http://www.ecologyandsociety. org/vol15/iss4/art20/

Folke, C., J. Colding, and F. Berkes. 2003. Synthesis: building resilience and adaptive capacity in social-ecological systems. Pages 352-387 in F. Berkes, J. Colding, and C. Folke, editors. Navigating social-ecological systems: building resilience for complexity and change. Cambridge University Press, Cambridge, UK. http://dx.doi.org/10.1017/CBO9780511541957.020

Folke, C., T. Hahn, P. Olsson, and J. Norberg. 2005. Adaptive governance of social-ecological systems. Annual Review of Environment and Resources 30:441-473. http://dx.doi. org/10.1146/annurev.energy.30.050504.144511

Font, N., and J. Subirats. 2010. Water management in Spain: the role of policy entrepreneurs in shaping change. Ecology and Society 15(2): 25. [online] URL: http://www. ecologyandsociety.org/vol15/iss2/art25/

Franzén, F., G. Kinell, J. Walve, R. Elmgren, and T. Söderqvist. 2011. Participatory social-ecological modeling in eutrophication management: the case of Himmerfjärden, Sweden. Ecology and Society 16(4): 27. http://dx.doi. org/10.5751/ES-04394-160427

Galaz, V., P. Olsson, T. Hahn, C. Folke, and U. Svedin. 2008. The problem of fit among biophysical systems, environmental and resource regimes, and broader governance systems: insights and emerging challenges. Pages 147-186 in O. R. Young, L. A. King, and H. Schroeder, editors. Institutions and environmental change: principal findings, applications, and research frontiers. MIT Press, Cambridge, Massachusetts, USA.

Garud, R., S. Jain, and A. Kumaraswamy. 2002. Institutional entrepreneurship in the sponsorship of common technological standards: the case of Sun Microsystems and Java. Academy of Management Journal 45(1):196-214. http://dx.doi. org $/ 10.2307 / 3069292$

Garud, R., and P. Karnoe. 2005. Distributed agency and interactive emergence. Pages 88-96 in S. W. Floyd, J. Roos, C. D. Jacobs, and F. W. Kellermanns, editors. Innovating strategy process. Wiley-Blackwell, Oxford, UK.

Gelcich, S., T. P. Hughes, P. Olsson, C. Folke, O. Defeo, M. Fernández, S. Foale, L. H. Gunderson, C. Rodríguez-Sieker,
M. Scheffer, R. S. Steneck, and J. C. Castilla. 2010. Navigating transformations in governance of Chilean marine coastal resources. Proceedings of the National Academy of Sciences 107:16794-16799. http://dx.doi.org/10.1073/pnas.1012021107

Gilmour, A., G. Walkerden, and J. Scandol. 1999. Adaptive management of the water cycle on the urban fringe: three Australian case studies. Conservation Ecology 3(1): 11. [online] URL: http://www.consecol.org/vol3/iss1/art11/

Gladwell, M. 2000. The tipping point: how little things can make a big difference. Little, Brown and Company, New York, New York, USA.

Goldstein, J. A., J. K. Hazy, and J. Silberstang. 2008. Complexity and social entrepreneurship: a fortuitous meeting. E:CO 10(3):9-24. [online] URL: http://www.complexityandsociety. com/files/4913/1717/4955/complexity_science_and_social_entrepreneurship a fortuitous meeting issue $1033 \mathrm{ac} . p \mathrm{df}$

Greenleaf, R. K. 2002. Servant leadership. Paulist, Mahwah, New Jersey, USA.

Gunderson, L. H., and C. S. Holling. 2002. Panarchy: understanding transformations in human and natural systems. Island, Washington, D.C., USA.

Gunderson, L. H., and S. S. Light. 2006. Adaptive management and adaptive governance in the everglades ecosystem. Policy Sciences 39(4):323-334. http://dx.doi. org/10.1007/s11077-006-9027-2

Gunderson, L. H, S. S. Light, and C. S. Holling. 1995. Barriers and bridges to the renewal of regional ecosystems. Columbia University Press, New York, New York, USA.

Hahn, T., P. Olsson, C. Folke, and K. Johansson. 2006. Trustbuilding, knowledge generation and organizational innovations: the role of a bridging organization for adaptive comanagement of a wetland landscape around Kristianstad, Sweden. Human Ecology 34:573-592. http://dx.doi. org/10.1007/s10745-006-9035-Z

Holling, C. S. 1986. The resilience of terrestrial ecosystems: local surprise and global change. Pages 292-317 in W. C. Clark and R. E. Munn, editors. Sustainable development of the biosphere. Cambridge University Press, Cambridge, UK.

Holling, C. S., and G. K. Meffe. 1996. Command and control and the pathology of natural resource management. Conservation Biology 10:328-337. http://dx.doi.org/10.1046/ j.1523-1739.1996.10020328.x

Huitema, D., and S. Meijerink. 2010. Realizing water transitions: the role of policy entrepreneurs in water policy change. Ecology and Society 15(2): 26. [online] URL: http:// www.ecologyandsociety.org/vol15/iss2/art26/

Imperial, M. T., and D. Kauneckis. 2003. Moving from conflict to collaboration: watershed governance in Lake 
Tahoe. Natural Resources Journal 43:1009-1056. [online] URL: http://www.academia.edu/514315/Moving from Conflict to Collaboration Watershed Governance in Lake Tahoe

Kenward, R. E., M. J. Whittingham, S. Arampatzis, B. D. Manos, T. Hahn, A. Terry, R. Simoncini, J. Alcorn, O. Bastian, M. Donlan, K. Elowe, F. Franzén, Z. Karacsonyi, M. Larsson, D. Manou, I. Navodaru, O. Papadopoulou, J. Papathanasiou, A. von Raggamby, R. J. A. Sharp, T. Söderqvist, A. Soutukorva, L. Vavrova, N. J. Aebischer, N. Leader-Williams, and C. Rutz. 2011. Identifying governance strategies that effectively support ecosystem services, resource sustainability, and biodiversity. Proceedings of the National Academy of Science 108(13):5308-5312. http://dx.doi.org/10.1073/ pnas. 1007933108

Lawrence, T. B. 1999. Institutional strategy. Journal of Management 25(2):161-187. http://dx.doi.org/10.1016/S0149-2063 (99) $80008-7$

Leach, W. D. 2001. Making watershed partnerships work: a review of the empirical literature. Journal of Water Resources Planning and Management 127:378-385. http://dx.doi. org/10.1061/(ASCE)0733-9496(2001)127:6(378)

Lichtenstein, B. B., and D. A. Plowman. 2009. The leadership of emergence: a complex systems leadership theory of emergence at successive organizational levels. Leadership Quarterly 20(4):617-630. http://dx.doi.org/10.1016/j.

leaqua.2009.04.006

Low, S., and T. Randhir. 2005. Watershed management, structural characteristics, information processing, and cooperative strategies in conservation organizations. Journal of Soil and Water Conservation 60:281-287.

Magnusson, S.-E. 2004. The changing perception of the wetlands in and around Kristianstad, Sweden: from waterlogged areas toward a future water kingdom, Kristianstads Vattenrike Biosphere Reserve. Annals of the New York Academy of Sciences 1023:323-327. http://dx.doi. org/10.1196/annals.1319.018

Maguire, S., C. Hardy, and T. B. Lawrence. 2004. Institutional entrepreneurship in emerging fields: HIV/AIDS treatment advocacy in Canada. Academy of Management Journal 47 (5):657-679. http://dx.doi.org/10.2307/20159610

Manring, S. L. 2007. Creating and managing interorganizational learning networks to achieve sustainable ecosystem management. Organization and Environment 20(3):325-346. http://dx.doi.org/10.1177/1086026607305738

Marton-Lefèvre, J., and G. M. Mehers. 2007. A look at the LEAD programme as a transformative experience. Futures 39 (5):619-624. http://dx.doi.org/10.1016/j.futures.2006.10.005

McAdam, D. 1996. Conceptual origins, current problems, future directions. Pages 23-40 in D. McAdam, J. D. McCarthy, and M. N. Zald, editors. Comparative perspectives on social movements. Cambridge University Press, Cambridge, UK.

McAdam, D., J. D. McCarthy, and M. N. Zald, editors. 1996. Comparative perspectives on social movements. Cambridge University Press, Cambridge, UK.

Meijerink, S., and D. Huitema. 2010. Policy entrepreneurs and change strategies: lessons from sixteen case studies of water transitions around the globe. Ecology and Society 15(2): 21. [online] URL: http://www.ecologyandsociety.org/vol15/iss2/ $\underline{\operatorname{art} 21 /}$

Napier, V.R., G. M. Branch, and J. M. Harris. 2005. Evaluating conditions for successful co-management of subsistence fisheries in KwaZulu-Natal, South Africa. Environmental Conservation 32:165-177. http://dx.doi.org/10.1017/

$\underline{\mathrm{S} 0376892905002195}$

National Research Council, Board on Sustainable Development. 1999. Our common journey: a transition toward sustainability. National Academies, Washington, D. C., USA.

Olsson, P., and C. Folke. 2001. Local ecological knowledge and institutional dynamics for ecosystem management: a study of Lake Racken Watershed, Sweden. Ecosystems 4:85-104. http://dx.doi.org/10.1007/s100210000061

Olsson, P., C. Folke, V. Galaz, T. Hahn, and L. Schultz. 2007. Enhancing the fit through adaptive co-management: creating and maintaining bridging functions for matching scales in the Kristianstads Vattenrike Biosphere Reserve, Sweden. Ecology and Society 12(1): 28. [online] URL: http://www. ecologyandsociety.org/vol12/iss1/art28/

Olsson, P., C. Folke, and T. Hahn. 2004. Social-ecological transformation for ecosystem management: the development of adaptive co-management of a wetland landscape in Southern Sweden. Ecology and Society 9(4): 2. [online] URL: http://www.ecologyandsociety.org/vol9/iss4/art2

Olsson, P., C. Folke, and T. P. Hughes. 2008. Navigating the transition to ecosystem-based management of the Great Barrier Reef, Australia. Proceedings of the National Academy of Sciences 105:9489-9494. http://dx.doi.org/10.1073/ pnas.0706905105

Olsson, P., and V. Galaz. 2012. Social-ecological innovation and transformation. Pages 223-243 in A. Nicholls and A. Murdock, editors. Social innovation: blurring boundaries to reconfigure markets. Palgrave Macmillan, Basingstoke, UK.

Olsson, P., L. H. Gunderson, S. R. Carpenter, P. Ryan, L. Lebel, C. Folke, and C. S. Holling. 2006. Shooting the rapids: navigating transitions to adaptive governance of socialecological systems. Ecology and Society 11(1): 18. [online] URL: http://www.ecologyandsociety.org/vol11/iss1/art18/ 
Osborn, R. N., and J. G. Hunt. 2007. Leadership and the choice of order: complexity and hierarchical perspectives near the edge of chaos. Leadership Quarterly 18(4):319-340. http://dx. doi.org/10.1016/j.leaqua.2007.04.003

Ostrom, E. 1990. Governing the commons: the evolution of institutions for collective action. Cambridge University Press, Cambridge, UK.

Padgett, J. F., and P. D. McLean. 2006. Transformation: the birth of partnership systems in Renaissance Florence. American Journal of Sociology 111(5):1463-1568. http://dx. doi.org/10.1086/498470

Pagdee, A., Y.-s. Kim, and P. J. Daugherty. 2006. What makes community forest management successful: a meta-study from community forests throughout the world. Society and Natural Resources 19:33-52. http://dx.doi.org/10.1080/08941920500323260

Pahl-Wostl, C. 2007. Transitions towards adaptive management of water facing climate and global change. Water Resources Management 21(1):49-62. http://dx.doi.org/10.1007/ s11269-006-9040-4

Perkmann, M., and A. Spicer. 2007. Healing the scars of history: projects, skills and field strategies in institutional entrepreneurship. Organization Studies 28(7):1101-1122. http://dx.doi.org/10.1177/0170840607078116

Pfueller, S. L. 2008. Role of bioregionalism in Bookmark Biosphere Reserve, Australia. Environmental Conservation 35:173-186. http://dx.doi.org/10.1017/S0376892908004839

Plowman, D. A., S. Solansky, T. E. Beck, L. Baker, M. Kulkarni, and D. V. Travis. 2007. The role of leadership in emergent self-organization. Leadership Quarterly 18 (4):341-356. http://dx.doi.org/10.1016/j.leaqua.2007.04.004

Rao, H. 1998. Caveat emptor: the construction of nonprofit consumer watchdog organizations. American Journal of Sociology 103(4):912-961. http://dx.doi.org/10.1086/231293

Raskin, P., M. Chadwick, T. Jackson, and G. Leach. 1996. The sustainability transition, beyond conventional development. SEI Report, Stockholm Environment Institute, Stockholm, Sweden.

Riddell, D., O. Tjörnbo, and F. Westley. 2012. Agency and innovation in a phase of turbulent change: conservation in the Great Bear Rainforest. Pages 155-180 in K. Golden-Biddle and J. E. Dutton, editors. Using a positive lens to explore social change and organization. Routledge, New York, New York, USA.

Rockström, J., W. Steffen, K. Noone, Å. Persson, F. S. Chapin, III, E. F. Lambin, T. M. Lenton, M. Scheffer, C. Folke, H. J. Schellnhuber, B. Nykvist, C. A. de Wit, T. Hughes, S. van der Leeuw, H. Rodhe, S. Sörlin, P. K. Snyder, R. Costanza, U.
Svedin, M. Falkenmark, L. Karlberg, R. W. Corell, V. J. Fabry, J. Hansen, B. Walker, D. Liverman, K. Richardson, P. Crutzen, and J. A. Foley. 2009. A safe operating space for humanity. Nature 461:472-475. http://dx.doi.org/10.1038/461472a

Shannon, M. A. 1991. Resource managers as policy entrepreneurs. Journal of Forestry 9(6):27-30.

Stankey, G. H., R. N. Clark, and B. T. Bormann. 2005. Adaptive management of natural resources: theory, concepts, and management institutions. U. S. Department of Agriculture, Portland, Oregon, USA. [online] URL: http:// www.fs.fed.us/pnw/pubs/pnw gtr654.pdf

Steffen, W., P. J. Crutzen, and J. R. McNeill. 2007. The Anthropocene: are humans now overwhelming the great forces of nature. AMBIO 36(8):614-621. http://dx.doi. org/10.1579/0044-7447(2007)36[614:TAAHNO]2.0.CO;2

Stephenson, M. O., Jr. 2010. Considering the relationships among social conflict, social imaginaries, resilience, and community-based organization leadership. Ecology and Society 16(1): 34. [online] URL: http://www.ecologyandsociety. org/vol16/iss1/art34/

Strang, D., and J. W. Meyer. 1993. Institutional conditions for diffusion. Theory and Society 22(4):487-511. http://dx.doi. org/10.1007/BF00993595

Suddaby, R., and R. Greenwood. 2005. Rhetorical strategies of legitimacy. Administrative Science Quarterly 50:35-67. [online] URL: http://www.business.ualberta.ca/en/FacultyAndStaff/ StrategicManagementandOrganization/RoySuddaby/Research/ / media/business/FacultyAndStaff/SMO/RoySuddaby/Documents/ SuddabyGreenwood.ashx

Sudtongkong, C., and E. Webb. 2008. Outcomes of state- vs. community-based mangrove management in southern Thailand. Ecology and Society 13(2): 27. [online] URL: http:// www.ecologyandsociety.org/vol13/iss2/art27/

Tarrow, S. 1996. States and opportunities: the political structuring of social movements. Pages 41-61 in D. McAdam, J. D. McCarthy, and M. N. Zald, editors. Comparative perspectives on social movements. Cambridge University Press, Cambridge, UK. http://dx.doi.org/10.1017/ CBO9780511803987.004

Trist, E. 1983. Referent organizations and the development of interorganizational domains. Human Relations 36:269-284. http://dx.doi.org/10.1177/001872678303600304

Uhl-Bien, M., R. Marion, and B. McKelvey. 2007. Complexity leadership theory: shifting leadership from the industrial age to the knowledge era. Leadership Quarterly 18(4):298-318. http://dx.doi.org/10.1016/j.leaqua.2007.04.002

Vasseur, L., L. Lafrance, C. Ansseau, D. Renaud, D. Morin, and T. Audet. 1997. Advisory committee: a powerful tool for 
helping decision makers in environmental issues. Environmental Management 21:359-365. http://dx.doi. org/10.1007/s002679900035

Walker, B., N. Abel, J. M. Anderies, and P. Ryan. 2009. Resilience, adaptability, and transformability in the GoulburnBroken Catchment, Australia. Ecology and Society 14(1): 12. [online] URL: http://www.ecologyandsociety.org/vol14/iss1/ $\underline{\operatorname{art} 12}$

Walker, B., C. S. Holling, S. R. Carpenter, and A. Kinzig. 2004. Resilience, adaptability and transformability in socialecological systems. Ecology and Society 9(2): 5. [online] URL: http://www.ecologyandsociety.org/vol9/iss2/art5/

Weick, K. E., and Westley, F. 1996. Organizational learning: affirming an oxymoron. Pages 440-458 in S. R. Clegg, C. Hardy, and W. R. Nord, editors. Handbook of organization studies. Sage, London, UK.

Westley, F. 1990. Middle managers and strategy: microdynamics of inclusion. Strategic Management Journal 11:337-351. http://dx.doi.org/10.1002/smj.4250110502

Westley, F. 2002. Devil in the dynamics. Pages 333-360 in L. H. Gunderson and C. S. Holling, editors. Panarchy: understanding transformations in human and natural systems theories for sustainable future. Island, Washington, D.C., USA.

Westley, F., and N. Antadze. 2010. Making a difference: strategies for scaling social innovation for greater impact. Innovation Journal 15(2):3-20. [online] URL: http://sig. uwaterloo.ca/sites/default/files/documents/MAKING_A_DIFFERENCE SiG Format.pdf

Westley, F., and H. Mintzberg. 1989. Strategic vision and strategic management. Strategic Management Journal 10:17-32. http://dx.doi.org/10.1002/smj.4250100704

Westley, F., P. Olsson, C. Folke, T. Homer-Dixon, H. Vredenburg, D. Loorbach, J. Thompson, M. Nilsson, E. Lambin, J. Sendzimir, B. Banerjee, V. Galaz, and S. van der Leeuw. 2011. Tipping toward sustainability: emerging pathways of transformation. AMBIO 40(7):762-780. http://dx. doi.org/10.1007/s13280-011-0186-9

Westley, F., and H. Vredenburg. 1997. Interorganizational collaboration and the preservation of global biodiversity. Organization Science 8(4):381-403. http://dx.doi.org/10.1287/ orsc.8.4.381

Westley, F., B. Zimmerman, and M. Q. Patton. 2006. Getting to maybe: how the world is changed. Random House, Toronto, Ontario, Canada.

Wheatley, M. J. 1994. Leadership and the new science: learning about organization from an orderly universe. BerrettKoehler, San Francisco, California, USA.
Wilder, M. 2010. Water governance in Mexico: political and economic apertures and a shifting state-citizen relationship. Ecology and Society 15(2): 22. [online] URL: http://www. ecologyandsociety.org/vol15/iss2/art22/

Wondolleck, J. M., and S. L. Yaffee. 2000. Making collaboration work: lessons from innovation in natural resource management. Island, Washington, D.C., USA.

Woolcock, M., and D. Narayan. 2000. Social capital: implications for development theory, research, and policy. World Bank Research Observer 5(2): 225-249. http://dx.doi. org/10.1093/wbro/15.2.225

Zimmerman, B. J., C. Lindberg, and P. E. Plsek. 1998. Edgeware: insights from complexity science for health care leaders. VHA, Dallas, Texas, USA.

Zimmerman, M. A., and G. J. Zeitz. 2002. Beyond survival: achieving new venture growth by building legitimacy. Academy of Management Review 27(3):414-431. 